\title{
Bakera: tradition of medicinal plants utilization for therapy, prevention and recovery of diseases in Jailolo Sultanate custom society, Indonesia
}

\author{
SITI AISYAH SYAHDAR ${ }^{1, \vartheta}$, M. NASIR TAMALENE ${ }^{2}$, SAID HASAN ${ }^{2}$ \\ ${ }^{1}$ Program of Biology Education, Universitas Khairun. Jl. Kampus II Gambesi, Ternate 97719, Maluku Utara, Indonesia. Tel/fax: +62-285-110-442-939, \\ vemail: aisyahmhalika@gmail.com \\ ${ }^{2}$ Departement of Biology Education, Universitas Khairun. Jl. Bandara Babullah Kampus 1, Ternate 97728, Maluku Utara, Indonesia
}

Manuscript received: 20 March 2019. Revision accepted: 20 October 2019.

\begin{abstract}
Syahdar SA, Tamalene MN, Hasan S. 2019. Bakera: tradition of medicinal plants utilization for therapy, prevention and recovery of diseases in Jailolo Sultanate custom society, Indonesia. Asian J Ethnobiol 2: 71-77. Indonesia is well-known as the source of tropical plants that are very useful for treating various diseases. In addition, there is also diverse traditional knowledge of herbal utilization in many societies. The eastern part of North Maluku Utara Province, the Jailolo Sultanate Society of Halmahera Island, consists of four original tribes: Gamkonora, Tobaru, Sahu, and Wayoli, still use traditional medicine to treat diseases. Their tradition called "Bakera" is similar to the 'Spa' in modern urban societies. Bakera, as one of the local geniuses in the medical field, has become an entrepreneurial interest, especially for those running the spa business. Medically, plants used in Bakera have been proven to affect health positively. This data may enrich other data on the wealth, diversity, and knowledge of medicinal plants of Indonesian communities. The research used emic and etic approaches. Data were analyzed descriptively, including presentation, reduction, verification, and validity check. Informants of the study were eight people selected using the Purposive Sampling Technique. Bakera can be used in the postpartum treatment and treat sore, malaria, and liver. As a whole, the use of nine different plant species for Bakera consists of medicinal and spice plants. There are three plant species found that is often cultivated in the yard. Bakera has thermotherapy and aromatherapy effects that contribute to Bakera effectiveness. Thermotherapy could alleviate muscle tension, lose weight, increase blood circulation, reduce tension headache, autoimmunity, and relaxation. In addition, plants used have immunostimulant, antiseptic, and antiphlogistic effects.
\end{abstract}

Keywords: Bakera, ethnic, Gamkonora, Halmahera, medicinal plants, Sahu, Tobaru, Wayoli

\section{INTRODUCTION}

Societies in developing countries are highly relied on local natural resources, including especially wild medicinal plants, to fulfill their needs on daily primary health treatment (Quave and Pieroni 2014). The diversity of traditional medicine is due to the variety of human societies, languages, and cultures, combined with local ecological diversity Novy (, 1997); Ndoye and Eyebe (1997).

Many ethnic communities in Indonesia have practiced the utilization of medicinal plants. Each ethnic has its knowledge of how to use various medicinal plants. This is a priceless asset, especially for developing the medical and pharmaceutical industry (Noorcahyati 2012). In human civilization, plants as medicine materials have been utilized since the era of gathering. It is inherited from previous generations and lasts until the present day, practiced by modern society. Local knowledge is every generation's heritage. This knowledge is usually owned by traditional healers (the Hattra), who are considered consistent in preserving and practicing local knowledge on utilizing various plants to create many traditional potions. However, many rural societies have become more familiar with modern medication and chemical medicines.

The growing interest in traditional medication cannot be separated from the ever-increasing complexity of diseases among societies and the increasing health expenses. As a result, traditional medicine has become one of the alternatives for people looking to solve health problems.

Supported by available natural resources and inherited knowledge of traditional medication, the interest keeps growing among the Jailolo Sultanate indigenous society in Halmahera Island, North Maluku Province, Indonesia. People's traditional potion processing methods include squeezed, fresh-consumed, boiled, mashed, and vaporization. Jailolo Sultanate indigenous society uses herbal material both in new conditions and after being dried.

There are two ways of processing medicine from plants, either boiled and squeezed or mashed. While there are three ways of serving it: drink it, rub it on the body, or wash it with water. Drinking potion is usually a treatment for inner body part diseases, while the other two are for outer body part treatments (Kusuma and Zaky 2005).

One unique method of traditional herbal medication practiced by the Jailolo Sultanate indigenous society is the Bakera or vaporization. Bakera is a treatment commonly used by four ethnicities under the Jailolo Sultanate: Gamkonora, Tobaru, Sahu, and Wayoli, who live in West Halmahera District, North Maluku Province. This is the most common treatment for women to keep them fit and fresh during their post-maternal phase. Its method is similar to the sauna and uses aromatic herbs. 
Sukenik et al. (1999) stated that a sauna is good for blood circulation. Minerals contained in the potion penetrate through the skin pores. Sauna has many therapeutic functions, including decreasing blood pressure, improving lung function, easing asthma and bronchitis, relieving pain, and improving joint mobility in rheumatic treatment (Hannuksela and Ellahham 2001). Sauna is also suitable for respiration, cardiac disease, hypertension, depression, pain reliever, auto-immunity, and relaxing fatigue (Crinnion 2011). Sauna is ideal for relaxation since it can improve blood circulation and relieve pain. The aroma of the herbal potion used in a sauna can also deliver a sedative effect (Taavoni et al., 2013).

Essential oil used in the sauna plants could evaporate, thus stimulating memory and emotional response. Apart from the inside, the brain, called the hypothalamus, will deliver messages through the whole body, converted to actions to release particular compounds that can make our body relaxed. Relaxation can cause the muscle to relax, thus reducing the production of adrenaline hormone, which in turn decreases blood pressure (Werdyastri et al., 2014).

Aromatherapy from essential oils can easily infiltrate into the blood circulation and then be excreted through the urinal system or exhalation (Maddocks-jennings and Wilkinson 2004). Aromatherapy can treat diseases, balancing and relaxing our body, mind, and soul, as well as stimulating the body immune system to cope with various health problems, such as respiratory diseases, gastroenteritis disease, neural disorder, as well as infection of bacteria and fungus (Alexander 2002; Reichling and Saller 2003, Suwanti et al. 2018).

Inhaling aromatherapy is considered the fastest and most direct healing method. That is because the easy-toevaporate molecules of essential oil directly react to olfactory organs, resulting in brain perception (Sustrani 2004).

The utilization of medicinal plants is a long-lasting tradition. Traditional knowledge or local genius of Jailolo Sultanate indigenous society in utilizing natural resources, especially medicinal plants, is a cultural treasure to be preserved. As such, authentic Indonesian knowledge will not be eliminated from civilization so that the medicinal plants will be based for utilization by the Jailolo Sultanate indigenous society. The research aims to discover traditional knowledge of Jailolo Sultanate indigenous society in utilizing medicinal plants to prevent (preventive), treat (curative), and recover (rehabilitative) diseases.

\section{MATERIALS AND METHODS}

The research was conducted from March to November 2018 at three sub-districts in West Halmahera District areas, North Maluku. Four villages were selected from the three sub-districts (Figure 1).

The research used a qualitative method with $a$ phenomenology approach using semi-structured interviews, observation, and documentation. Informants were selected through purposive sampling (Figure 2).
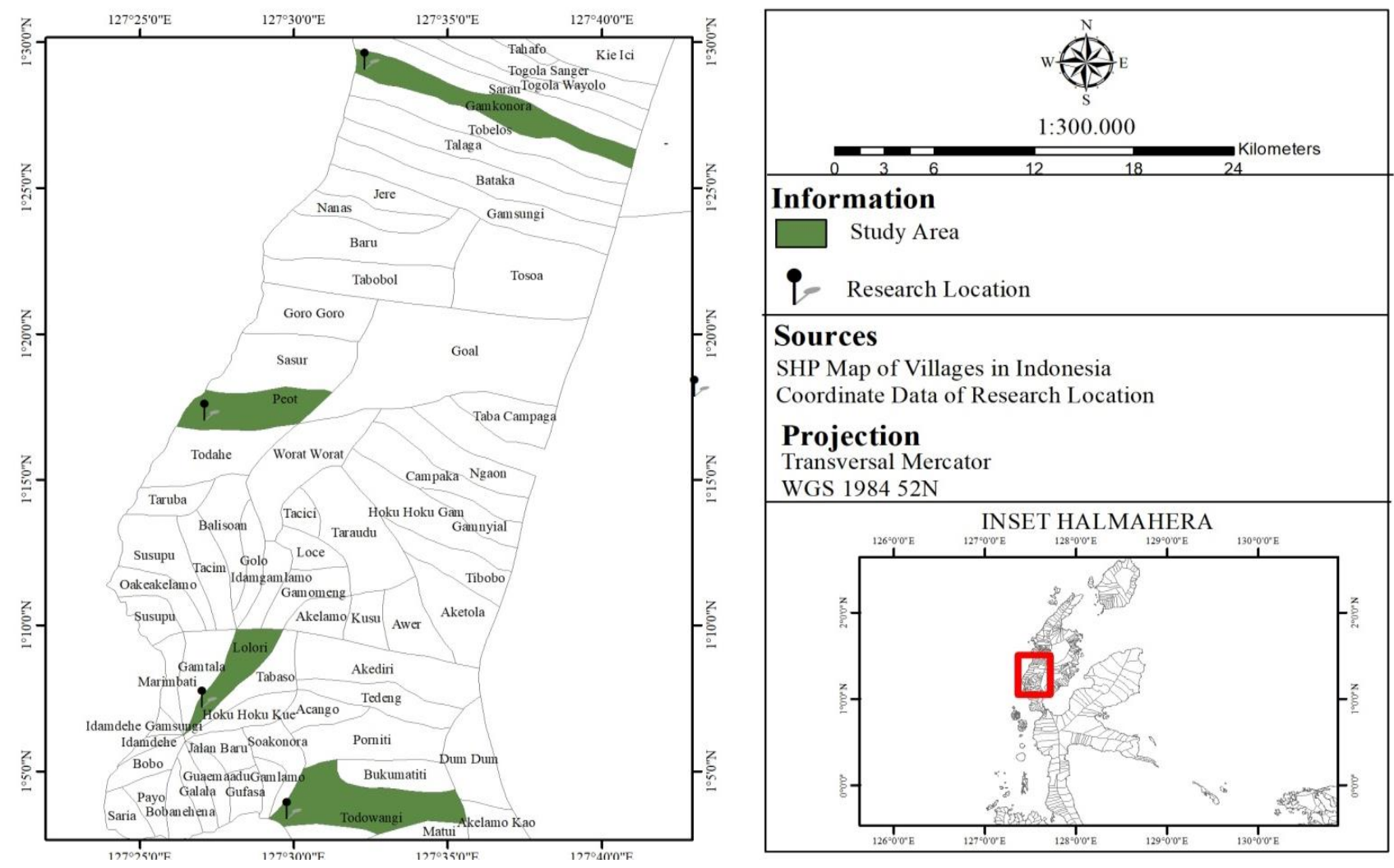

Figure 1. Map of the study area in Jailolo, West Halmahera District, North Maluku Province, Indonesia 


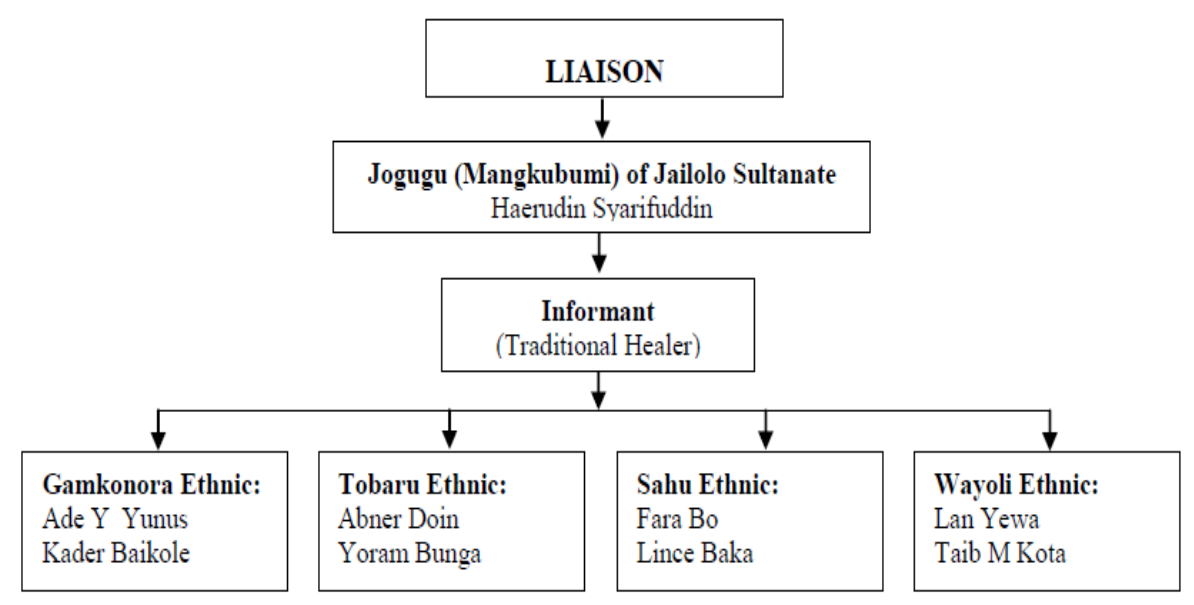

Figure 2. Assignment of Research Informants

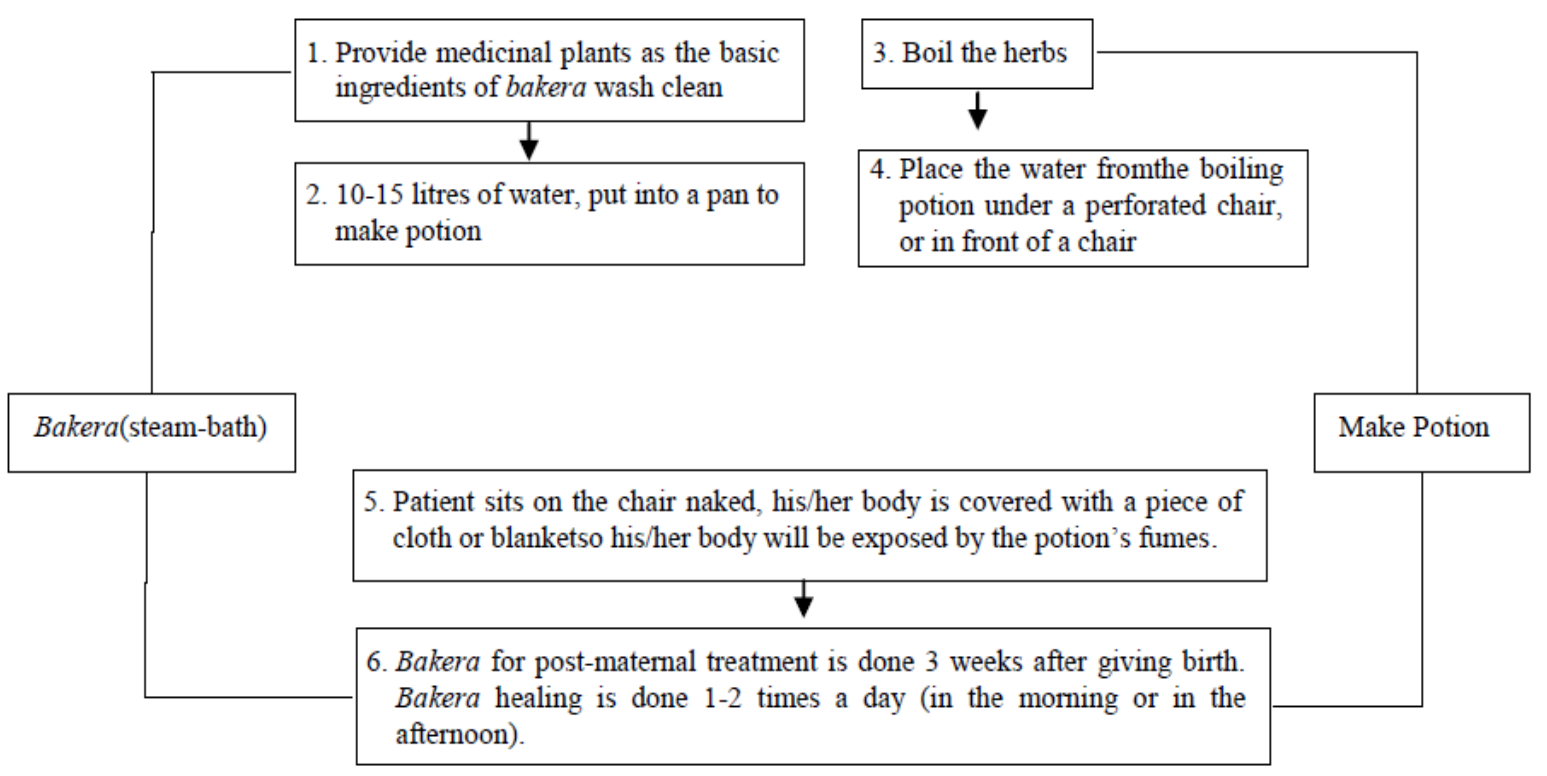

Figure 3. The common process of Bakera

The Informants of the research were eight people. The selection was based on 1) Healing period/level of healing practice to represent the level of skill and knowledge; 2) knowledge on medicinal plants utilization, and; 3) already having pupils that will inherit their knowledge. Besides becoming a hattra (traditional healer), informants were also peasants. Informants from the Gamkonora Ethnic reside in Gamkonora Village, South Ibu Sub-district. Informants from the Sahu Ethnic live in Lolori Village, Jailolo Subdistrict. Informants from the Tobaru Ethnic reside in Todowongi Village, Jailolo sub-district, informants from the Wayoli ethnic reside in Peot Village, Sahu Sub-district. All of them are still practicing traditional medication in their daily life. Informants' age is between 51 and 70 years old with an average level of education is not graduated from elementary school (only one informant who is a high school graduate).
Each informant was asked for information concerning medicinal plants and their utilization and processing method practiced. The identification of plants used in medication was made directly on the field. The identification process was based on the plant's morphological characteristics (root, stem, leaf, flower, seed, and fruit). Plant identification method used plant identification guidebook by the Medicinal Plants Center. Unidentified plants will be identified by matching plants' organs with determination keys using Steenis (2008) book. Results were analyzed descriptively by presenting data in figures and tables. Results are analyzed by data presentation, reduction, verification, and validity check. A map of the research location can be seen in figure 2 . 


\section{RESULTS AND DISCUSSION}

The Jailolo Sultanate indigenous society has an authentic traditional medical treatment method called the Bakera. Bakera is a traditional way of steam-bathing using the medical plants for healing, recovery, and preventing diseases. The word 'Bakera' is derived from the Minahasa language of Sulawesi Utara (North Sulawesi), first explained by Watuseke in 1970 (Watuseke 2014). Bakera tradition can be considered the "Spa" (Salus per aqum) " in modern societies. Knowing of healing, prevention, and recovery using medicinal plants is inherited hereditary in local medication. From the medical aspect, medicinal plants used in Bakera were proven to positively affect health by simply supporting the body's immune system. Bakera, as one of the local knowledge in medical practices in North Maluku, has attracted entrepreneurial interest. Generally, the method used in Bakera is presented in Figure 3, and Bakera process documentation is shown in Figure 4.

Body treatment is important, not only for women but also for men. The women of Jailolo Sultanate indigenous society have been doing the Bakera for generations. This treatment is mainly done by those who have just given birth to a baby (three or four weeks after birth). Yet, Bakera is done for post-maternal treatment and many kinds of disease (Table 1.)

Table 1. Bakera for medication, recovery, and prevention of various diseases

\begin{tabular}{|c|c|c|c|}
\hline Ethnic & $\begin{array}{c}\text { Disease } \\
\text { treated using } \\
\text { Bakera } \\
\text { method }\end{array}$ & Potion making method & Serving/applying method \\
\hline \multirow[t]{3}{*}{ Gamkonora } & Liver disease & $\begin{array}{l}\text { Provide } 17 \text { handfuls of clove leaves, } \\
17 \text { handfuls of nutmeg leaves, a } \\
\text { piece of dried banana leaf, and } 20 \mathrm{~cm} \\
\text { of mangosteen bark. } \\
\text { Prepare } 10-20 \text { liter of water, put all } \\
\text { the ingredients into the water, and } \\
\text { boil the potion. }\end{array}$ & $\begin{array}{l}\text { Drink a half glass of boiled potion water, and put the rest under a } \\
\text { perforated wooden chair. The patient sits naked on the chair, } \\
\text { covered by a piece of the blanket so that their whole body will be } \\
\text { exposed to the hot steam coming from the boiling potion. The } \\
\text { treatment can be done once a week until the patient feels } \\
\text { recovered. }\end{array}$ \\
\hline & $\begin{array}{l}\text { Post-maternal } \\
\text { treatment }\end{array}$ & $\begin{array}{l}\text { Provide } 20 \text { handfuls of clove leaves, } \\
\text { wash clean; } 20 \text { handfuls of nutmeg } \\
\text { leaves, } 1 \text { dried banana leaf, } 20 \mathrm{~cm} \text { of } \\
\text { mangosteen bark. } \\
\text { Prepare } 10-20 \text { liter of water, put all } \\
\text { the ingredients into the water, and } \\
\text { boil the potion. }\end{array}$ & $\begin{array}{l}\text { Place the boiled potion under a perforated wooden chair. The } \\
\text { patient (the mother) sits naked on the chair, covered by a piece of } \\
\text { the blanket so that her whole body will be exposed by the hot } \\
\text { steam that comes from the boiling potion. The treatment is done } \\
\text { twice a day (in the morning and the afternoon) for a month. The } \\
\text { treatment can be applied one month after giving birth. }\end{array}$ \\
\hline & $\begin{array}{l}\text { Treatment of } \\
\text { Malaria }\end{array}$ & $\begin{array}{l}\text { Provide } 20 \text { handfuls of clove leaves, } \\
\text { wash clean; } 20 \text { handfuls of nutmeg } \\
\text { leaves, } 1 \text { dried banana leaf, and } 40 \\
\mathrm{~cm} \text { of the langsat fruit bark. } \\
\text { Prepare 10-20 liter of water, put all } \\
\text { the ingredients into the water, and } \\
\text { boil the potion. }\end{array}$ & $\begin{array}{l}\text { Place the boiled potion under a perforated wooden chair. The } \\
\text { patient sits naked on the chair, covered by a piece of the blanket } \\
\text { so that their whole body will be exposed to the hot steam that } \\
\text { comes from the boiling potion. Bakera is practiced in the } \\
\text { morning and afternoon until the patient sweats. Treatment is } \\
\text { done after the patient recovered from the disease. }\end{array}$ \\
\hline Sahu & $\begin{array}{l}\text { Post-maternal } \\
\text { treatment }\end{array}$ & $\begin{array}{l}\text { Provide } 17 \text { handfuls of clove leaves, } \\
\text { wash clean; } 17 \text { handfuls of nutmeg } \\
\text { leaves, } 1 \text { dried banana leaf, and } 30 \\
\text { cm of the langsat fruit bark. } \\
\text { Prepare } 10-20 \text { liter of water, put all } \\
\text { the ingredients into the water, and } \\
\text { boil the potion. }\end{array}$ & $\begin{array}{l}\text { Place the boiled potion under a perforated wooden chair. The } \\
\text { patient (the mother) sits naked on the chair, covered by a piece of } \\
\text { the blanket so that her whole body will be exposed by the hot } \\
\text { steam that comes from the boiling potion. The treatment is } \\
\text { executed twice a day (in the morning and the afternoon) for a } \\
\text { month. The treatment can be performed one month after giving } \\
\text { birth. }\end{array}$ \\
\hline Tobaru & $\begin{array}{l}\text { Post-maternal } \\
\text { treatment }\end{array}$ & $\begin{array}{l}\text { Provide } 20 \text { handfuls of clove leaves, } \\
\text { wash clean; } 20 \text { handfuls of nutmeg } \\
\text { leaves, } 1 \text { dried banana leaf, } 30 \mathrm{~cm} \text { of } \\
\text { the langsat fruit bark. } 1 \text { papaya leaf, } \\
15 \text { handfuls of sea daisy leaves. } \\
\text { Prepare } 10-20 \text { liter of water, put all } \\
\text { the ingredients into the water, and } \\
\text { boil the potion. }\end{array}$ & $\begin{array}{l}\text { Place the boiled potion under a perforated wooden chair. The } \\
\text { patient (the mother) sits naked on the chair, covered by a piece of } \\
\text { the blanket so that her whole body will be exposed by the hot } \\
\text { steam that comes from the boiling potion. The treatment is } \\
\text { executed twice a day (in the morning and the afternoon) for a } \\
\text { month. The treatment can be performed applied one month after } \\
\text { giving birth. }\end{array}$ \\
\hline Wayoli & Relief pain & $\begin{array}{l}\text { Provide } 17 \text { handfuls of clove leaves, } \\
\text { wash clean; } 17 \text { handfuls of nutmeg } \\
\text { leaves, } 1 \text { dried banana leaf, and } 30 \\
\text { cm of mangosteen bark. } \\
\text { Prepare } 5-10 \text { liter of water, put all } \\
\text { the ingredients into the water, and } \\
\text { boil the potion. }\end{array}$ & $\begin{array}{l}\text { Place the mixture under a hollow wooden chair. The patient sits } \\
\text { naked on the chair, covered by a piece of the blanket so that their } \\
\text { whole body will be exposed to the hot steam that comes from the } \\
\text { boiling potion. The treatment can be done once a week until the } \\
\text { patient feels recovered. }\end{array}$ \\
\hline
\end{tabular}




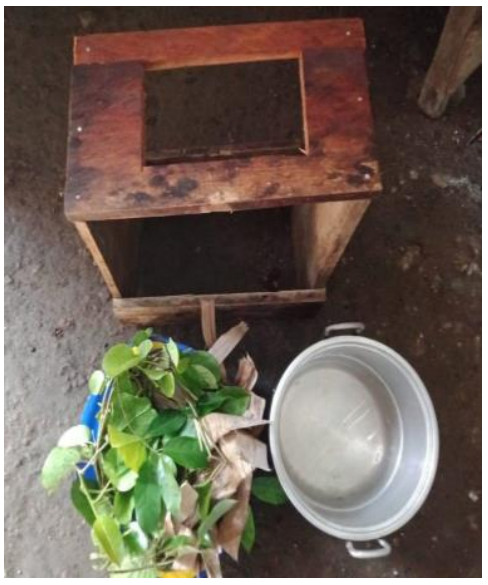

A

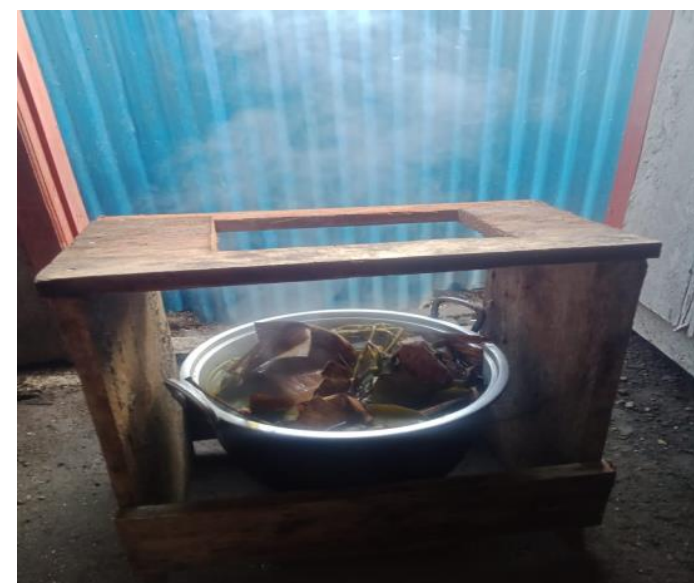

B

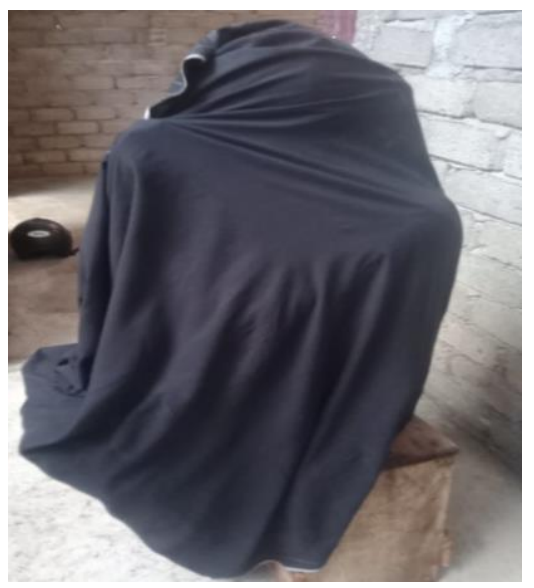

C

Figure 4. A. Tools and materials, B. Ready-to use-potion, and C. Bakera process

Table 2. Plants used in Bakera

\begin{tabular}{lllllc}
\hline \multicolumn{1}{c}{ Family } & Local name & Commercial name & Scientific name & Habitus & Part(s) used \\
\hline Asteraceae & Cinga-cinga & Sea daisy & Melanthera biflora L. Wild & Bush & Leaf \\
Caricaceae & Pupaya & Papaya & Carica papaya L. & Tree & Leaf \\
Clusiaceae & Mangustan & Mangosteen & Garcinia mangostana L. & Tree & Bark \\
Convolvulaceae & Loloro & Bayhops & Ipomea pes-caprae & Bush & Leaf, stem \\
Meliaceae & Lansa & Langsat & Lansium domesticum & Tree & Bark \\
Musaceae & Pisang & Banana & Musa textilia & Tree & Leaf \\
Myristicaceae & Pala & Nutmeg & Myristica fragrans Houtt. & Tree & Leaf \\
Myrtaceae & Cengkeh & Clove & Syzygium aromaticum & Tree & Leaf \\
\hline
\end{tabular}

Bakera uses potions made from medicinal plants suitable for disease medication, recovery, prevention and produces unique fragrances. The research found eight plants used in the Bakera, from spices to seashore bushes. A complete list of plants used as the ingredients of Bakera, along with their local and scientific name, habitus, parts, and family presented in Table 2.

All parts of medicinal plants have medical efficacy. However, the most commonly used part is the leaf, which takes $75 \%$ of all components (Figure 5). It is not hard to find those plants in the backyard of the home of Jailolo Sultanate indigenous society since most of their home nearly cannot be separated from those plants. It is just like plants for food and living.

Bakera, or a traditional sauna that uses medicinal plants, was explained in detail for the first time by Zumsteg and Weckerle (2007). Steam-bathing using many kinds of medicinal plants is a traditional method practiced by the people of North Sulawesi, mainly done by post-maternal mothers. Indigenous society believes that steam-bathing positively relaxes the body, improves blood circulation, and reduces body weight.

Bakera is applied one month after giving birth. According to the belief of Jailolo Sultanate indigenous society, a mother who just gave birth to a baby has an 'immature' body and would not be strong enough to take a Bakera treatment. That is why it is performed one month afterward. This method is also expected to make the body becomes fitness and healthy.

For Jailolo Sultanate indigenous society, the benefit of Bakera can be felt physically and mentally by their mind. These people said that after taking Bakera, their body feels more relaxed and fragrant. They feel more comfortable, and their mind also becomes more flexible. Bakera is considered to cure, prevent, and recover particular diseases. According to Taavoni et al. (2013), steam-bathing is good for relaxation since it can improve blood circulation and relieve pain.

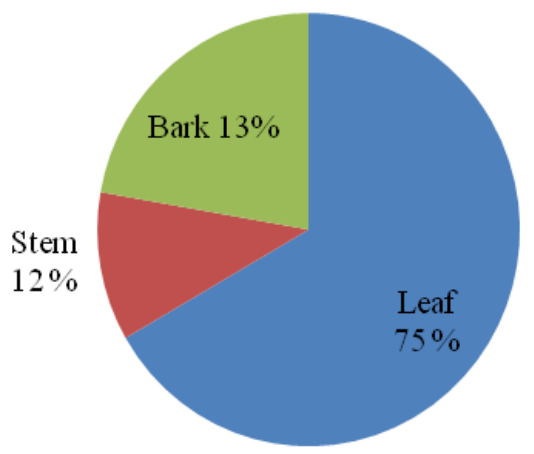

Figure 5. The proportion of medicinal plants' parts used in Bakera 
The Jailolo Sultanate indigenous society also said that the medicinal plants used and the vaporization in Bakera can prevent diseases. Medicinal plants boiled and inhaled by the Bakera patient act like medicine for their body. During the vaporization, the patient's body produces sweat. They believe that sweat brings out poisons from inside their body. That is why they feel healthier and fresher after taking Bakera.

The utilization of medicinal plants in Bakera provides a particular effect. The Bakera used plants from the family of Asteraceae (Sea daisy), Myrtaceae (Clove), Convolvulaceae (Bayhops), Meliaceae (Langsat fruit), Clusiaceae (Mangosteen), Myristicaceae (Nutmeg), Caricaceae (Papaya), Musaceae (Banana). Almost all ingredients have good effects on healing disease, medication, prevention, and recovery. As presumed by the local society, the efficacy of plants is nearly similar to what has been clinically tested. Studies have been conducted on some of those plants and reported on international journals, such as clove, nutmeg, sea hops, papaya, mangosteen, langsat, and banana.

Secondary metabolite compounds in clove leave act as an antibacterial agent (Nanan 2004). The main content of clove oil is eugenol, eugenol acetate, and caryophyllene. The Eugenol compound is a significant component in clove is an essential oil with antioxidant, antifungal, analgesic, and antiseptic activities. Clove oil has a unique taste and aroma favored by many people. In addition, the oil has stimulant, anesthetic, carminative, antiemetic, antiseptic, and antispasmodic nature (Altman and Marcussen 2001; Nanan 2004; Kumala 2008).

Methanol extract from nutmeg leaves contains alkaloids, flavonoids, terpenoids, acetate, and tannin compounds. At the same time, the ethyl acetate extract contains a flavonoid compound used as an antioxidant and antibacterial. It also has antifungal activity against $C$ andida albicans. Nutmeg leaves' acetyl extract has antibacterial activity against $S$. aureus and E. coli (Ginting et al., 2017). The essential oil in nutmeg is approximately $5-15 \%$ consisting of pinene, sabinene, camphene, myristicin, elemicin, isoelemicin, eugenol, isoeugenol, methoxyeugenol, safrole, dimeric polypropanoate, lignin, and neolignan (Janssens et al. 1990; Sonavane et al. 2001). According to Orita et al. (2003), one of the essential components in nutmeg fruit is myristicin, which has hepatoprotective activity.

Contents of plant langsat that are medically beneficial include essential oil, saponin, tannin, and organic acid. Venkateshappa and Sreenath (2013) suggested that the contents of langsat can be used as a pain reliever, antifungal, anti-inflammatory, tonic, and infection prevention. Phytochemical screening done by Poeloengan and Praptiwi (2010) on mangosteen shows alkaloid, tannin, phenolic, flavonoid, and triterpenoid compounds. Those compounds are known for having an antibacterial nature. The extract of the dry banana leaf contains secondary metabolite compounds of tannin, phenol, and flavonoid (Putra 2014). Tannin is one of the free radical predators (Kumari and Jain 2012).
Papaya leaves contain vitamins such as vitamin A, C, and $\mathrm{E}$ and alkaloids as the main antioxidant (Fitria et al., 2013). Antioxidant compounds can prevent damage caused by the free radical on normal cells, proteins, and fat. The utilization of medicinal plants in Bakera provides special effects since they contain various kinds of secondary metabolite compounds. This compound is a bioactive substance related to the chemical included. Secondary metabolic is only found in specific organisms and produced under particular conditions (Sudha and Ravishankar 2002).

Generally, secondary metabolite compound has an activity and function as a protector for the plant against pests for the sake of the plant itself and the surrounding environment. A chemical compound resulting from secondary metabolite has been broadly used as a dye, poison, aroma, food, medicines, and so on (Hayati and Fasyah 2010).

Essential oil content in Bakera ingredients will evaporate and stimulate memory and emotional responses. A part of the brain called the hypothalamus would deliver messages to the body that will be converted to actions in unleashing compounds that can relax the body. Relaxation can make muscles relaxed as well. This condition will decrease the production of adrenaline, which eventually will be resulted in reduced blood pressure ( Werdyastri et al., 2014).

Fresh plants are added to the hot water when the essential oil evaporates. Essential oil concentration resulting from the evaporation process is high enough to induce physiological effects, both from inhalation and skin condensation on infected or inflamed perineum areas (Boer et al., 2011).

The essential oil is inhaled and applied to the skin surface through evaporation. It may also penetrate through women's blood circulation (Bronaugh et al., 1990). Essential oil from plants used in Bakera supports the healing process, primarily through tonic effect. It may also prevent infection since it contains antiseptic and antiphlogistic.

Through the evaporated potion, Jailolo Sultanate indigenous society communities believe that Bakera will immediately recover their stamina and health, improve the blood circulation of post-maternal mothers, and rejuvenate skin texture from wrinkles after pregnancy. Bakera also is believed as a detoxification method after giving birth. It has been reported that steam-bathing can deep-cleanse our skin, enhance body weight, improve blood circulation, enhance muscle recovery, relieve headache, and be good for relaxation (Hannuksela and Ellahham 2001; Iwase et al. 2013; Crinnion 2011).

In summary, the traditional community of Jailolo Sultanate used nine types of medicinal plants for Bakera treatment, namely: Melanthera biflora L. Wild, Carica papaya L., Garcinia mangostana L., Ipomea pes-caprae, Lansium domesticum, Musa textilia, Myristica fragrans Houtt., and Syzygium aromaticum. These plants were used to treat, recover, and prevent diseases such as malaria, liver, soreness, and postpartum treatment using the Bakera method. All plants used in the Bakera contained secondary metabolite compounds, including eugenol, alkaloids, 
flavonoids, terpenoids, tannins, phenolic, organic acids, and vitamins, such as vitamin $\mathrm{A}, \mathrm{C}$, and $\mathrm{E}$. The secondary metabolite compounds in Bakera plant were used as medicine to treat various diseases. Bakera effectiveness contributed to thermotherapy and aromatherapy effects; hence, it could alleviate symptoms such as muscle tension, loss of weight, increased blood circulation, reduce tension headache, autoimmunity, immunostimulant, antiseptic, and antiphlogistic.

\section{ACKNOWLEDGEMENTS}

The authors thank the Sultan of Jailolo and the people of Jailolo Sultanate indigenous society for their support study during data collection on sites.

\section{REFERENCES}

Alexander M. 2002. Aromatherapy and immunity: How the use of essential oils aids immune potentiality. Int J Aromather 12 (1): 49-56. DOI: 10.1054/ijar.2001.0117.

Altman RD, Marcussen KC. 2001. Effects of a ginger extract on knee pain in patients with Osteoarthritis. Arthritis Rheum 44 (11): 2531-2538. DOI: 10.1002/1529-0131(200111)44:113.0.CO;2-J.

Boer HJDe, LamxayV, Björk L. 2011. Steam sauna and mother roasting in Lao PDR: practices and chemical constituents of essential oils of plant species used in postpartum recovery. BMC Complement Altern Med 11 (1): 128. DOI: 10.1186/1472-6882-11-128.

Bronaugh RL, Westert RC, Buckst D, Maibacht HI, Sarason R. 1990. In vivo percutaneous absorption of fragrance ingredients in rhesus monkeys and humans. Food Chem Toxicol 28 (5): 369-373. DOI: 10.1016/0278-6915(90)90111-Y.

Crinnion WJ. 2011. Sauna is a valuable clinical tool for cardiovascular, autoimmune, toxicant induced, and other chronic health problems. Altern Med Rev 16 (3): 215-225.

Hayati EK, Fasyah AG. 1990. Fraksinasi dan identifikasi senyawa tanin pada daun belimbing wuluh (Averrhoa bilimbi L.). Jurnal Kimia 4 (2) 193-200.

Fitria NA, Sidi NC, Safitri RK, Hasanah AN, Risni T. 2013. Tempe daun pepaya sebagai alternatif terapi untuk penderita kanker. Jurnal Teknosains Pangan 2(4). [Indonesian]

Ginting B, Mustanir M, Helwati H, Desiyana LS, Eralisa E, Mujahid R. 2017. Antioxidant activity of n-hexane extract of nutmeg plants from South Aceh Province. Jurnal Natural 17 (1): 39-44. DOI: 10.24815/jn.v17i1.6969. [Indonesian]

Hannuksela ML, Ellahham S. 2001. Benefits and risks of sauna bathing. Am J Med 110 (2): 118-126. DOI: 10.1016/S0002-9343(00)00671-9.

Iwase S, Kawahara Y, Nishimura N, Takada H, Nagata M. 2013. Effects of dry and mist saunas on circulatory and thermoregulatory functions in humans. Health 5 (2): 267-273. DOI: 10.4236/health.2013.52036.

Janssens J, Laekeman GM, Pieters LA, Totte J, Herman AG, Vlietinck A J. 1990. Nutmeg oil: identification and quantitation of its most active constituents as inhibitors of platelet aggregation. J Ethnopharmacol 29 (2): 179-188. DOI: 10.1016/0378-8741(90)90054-W

Kumala S. 2008. Efek Antibakteri Ekstrak Etanol Daun Cengkeh Eugenia aromatic L.). Jurnal Farmasi Indonesia 4 (2): 82-87. [Indonesian]

Kumari M, Jain S. 2012. Tannins : An antinutrient with positive effect to manage diabetes mechanism for lowering blood glucose levels. Res J Recent Sci 1 (12): 1-4.

Kusuma FR, Zakky BM. 2005. Tumbuhan Liar Berkhasiat Obat. PT. Agro Media Pustaka.
Maddocks-jennings W, Wilkinson JM. 2004. Aromatherapy practice in nursing: literature review. J Adv Nursing 48 (1): 93-103. DOI: 10.1111/j.1365-2648.2004.03172.x.

Morita T, Jinno K, Kawagishi H, Arimoto Y, Suganuma H, Inakuma T, Sugiyama K. 2003. Hepatoprotective effect of myristicin from nutmeg (Myristica fragrans) on lipopolysaccharide/d-galactosamineinduced liver injury. J Agric Food Chem 51( 6): 1560-1565. DOI: $10.1021 /$ jf020946n.

Nanan N. 2004. Diversifikasi penggunaan cengkeh. Jurnal Perspektif 3 (2): 61-70. DOI: 10.21082/p.v3n2.2004.61-70. [Indonesian]

Ndoye O, Pérez MR, Eyebe A. 1997. The markets of non-timber forest products in the humid forest zone of Cameroon. Overseas Development Institute, London.

Noorcahyati. 2012. Konservasi Eks Situ Tumbuhan Hutan Berkhasiat Obat Di KHDTK Samboja. Majalah Swara Samboja I/no.03/2012. Samboja: 02-05. [Indonesian]

Novy JW. 1997. Medicinal plants of the eastern region of Madagascar. J Ethnopharmacol 55: 119-126. DOI: 10.1016/S0378-8741(96)014894.

Poeloengan M, Praptiwi P. 2010. Ujiaktivitas antibakteri ekstrak kulit buah manggis (Gardnia mangostana Linn). Media Penelitian dan Pengembangan Kesehatan 20 (2): 65-69. [Indonesian]

Putra AAB, Bogoriani NW, Diantariani NP, Sumadewi NLU. 2014. Ekstraksi zat warna alam dari bonggol tanaman pisang (Musa paradiasciaca L.) dengan metode maserasi, refluks, dan sokletasi. Jurnal Kimia. DOI: 10.24843/JCHEM.2014.v08.i01.p18. [Indonesian]

Quave CL, Pieroni A. 2014. Fermented foods for food security and food sovereignty in the Balkans: a case study of the Gorani people of Northeastern Albania. J Ethnobiol 34 (1): 28-44. DOI: 10.2993/02780771-34.1.28.

Reichling J, Saller R. 2003. Johanniskraut (Hypericum perforatum L.)Vielstoffgemische kontra phytogene Einzelstoffe. Complement Med Res 10(Suppl. 1): 28-32. DOI: 10.1159/000071689.

Sonavane G, Sarveiya V, Kasture V, Kasture SB. 2001. Behavioral actions of myristica fragrans behavioural actions of Myristica Fragrans seeds. Indian J Pharmacol 33 (6): 417-424.

Steenis CGGJvan. 2008. Flora, Diterjemahkan dari Bahasa Belanda oleh Moeso Surjowinoto. PT. Pradnya Paramita, Jakarta, Indonesian

Sudha G, Ravishankar GA. 2002. Involvement and interaction of various signaling compounds on the plant metabolic events during defense response, resistance to stress factors, formation of secondary metabolites, and their molecular aspects. Plant Cell Tissue Organ Cult 71 (3): 181-212. DOI: 10.1023/A:1020336626361.

Sukenik S, Flusser D, Abu-Shakra M. 1999. The role of spa therapy in various rheumatic diseases. Rheum Dis Clin N Am 25 (4): 883-897. DOI: $10.1016 / \mathrm{S} 0889-857 \mathrm{X}(05) 70108-3$.

Sustrani L. 2004. Vita Health Hipertensi. PT Gramedia Pustaka Utama, Jakarta, Indonesian

Suwanti S, Wahyuningsih M, Liliana A. 2018. Pengaruh aromaterapi lemon (Cytrus) terhadap penurunan nyeri menstruasi pada mahasiswi di universitas respati yogyakarta. Jurnal Keperawatan Respati Yogyakarta 5 (1): 345-349.

Taavoni S, Darsareh F, Joolaee S, Haghani H. 2013. The effect of aromatherapy massage on the psychological symptoms of postmenopausal Iranian women. Complement Ther Med 21 (3): 158163. DOI: 10.1016/j.ctim.2013.03.007

Venkateshappa SM, Sreenath KP. 2013. Potential medicinal plants of Lamiaceae. Am Int J Res Formal Appl Nat Sci 1 (3): 82-87.

Watuseke FS. 1970. Oude gebruiken bij zwangerschap en geboorte in Tondano. Bijdragen tot de taal, land-en volkenkunde 126: 448-454. DOI: $10.1163 / 22134379-90002800$.

Werdyastri A, Armiyati Y, Kusuma. 2014. Perbedaan efektifitas aromaterapi lemon dan relaksasi nafas dalam terhadap penurunan tekanan darah pada pasien hipertensi di RSUD Tugurejo Semarang. Karya Ilmiah 388: 1-11.

Zumsteg IS, Weckerle CS. 2007. Bakera, a herbal steam bath for postnatal care in Minahasa (Indonesia): Documentation of the plants used and assessment of the method. J Ethnopharmacol 111 (3): 641-650. DOI: 10.1016/J.JEP.2007.01.016. 